\title{
ASYMBIOTIC SEED GERMINATION AND PLANTLET DEVELOPMENT OF COELOGYNE FUSCESCENS LINDL., A MEDICINAL ORCHID OF NEPAL
}

\author{
Dharma Koirala*, Shreeti Pradhan* and Bijaya Pant* \\ *Central Department of Botany, Tribhuvan University, Kirtipur, Nepal.
}

\begin{abstract}
Coelogyne fuscescens Lindl. is one of the commercially threatened epiphytic orchid of Nepal. It has reported to have medicinal properties as its pseudobulb is used to reduce the abdominal pain. Germination of the orchid seeds in nature is difficult without the symbiotic association of the Mycorrhizal fungi, Rhizoctonia species. Therefore, the present research was focused to study the effect of growth hormones on asymbiotic seed germination and their subsequent development into plantlets. Immature seeds of this orchid species cultured in MS media supplemented with different concentrations of 6 - Benzylaminopurine, BAP $(0.5 \mathrm{mg} / \mathrm{l}-2 \mathrm{mg} / \mathrm{l})$ and $\alpha$-Napthalene Acetic Acid, NAA $(0.5 \mathrm{mg} / \mathrm{l})$, singly and in combination showed various responses on germination and seedling development. MS medium supplemented with BAP $(1.0 \mathrm{mg} / \mathrm{l})$ plus NAA $(0.5 \mathrm{mg} / \mathrm{l})$ was found to be the most favourable condition for the early seed germination and protocorm development while medium supplemented with NAA $(0.5 \mathrm{mg} / \mathrm{l})$ was found to be favourable for their further differentiation into plantlets.
\end{abstract}

Keywords: Seed; in-vitro culture; MS media; tissue culture; protocorms.

\section{INTRODUCTION}

Orchids are one of the most beautiful ornamental plants of Nepal. Nepalese orchids are very popular due to their shape, size, habit, habitat, colourful flowers, shining green leaves and variously shaped pseudobulbs, so are highly used for horticultural purpose (White and Sharma, 2000). Beside their ornamental values many orchid species have medicinal as well as edible values (Baral and Kurmi, 2006; Pant, 2011).

Orchid seeds are very unique than the seeds of other flowering plants. They are very minute, dust like and produced in large numbers within a capsule or pod but lacks storage tissue. Therefore orchid seeds require mycorrhizal association for their germination in nature which is a very slow process (Mitra,1986). This problem can be overcome by asymbiotic germination of orchid seeds using in vitro culture techniques. During last few years, this technique has been highly exploited for mass propagation of many threatened orchid species (Stewart and Kane, 2006; Hossain, 2008; Pant et al. 2011).

Twelve species of Coelogyne has been recorded from Nepal (Raskoti, 2009). Among them, C. fuscescens Lindl. is one of the important ornamental species because of its coconut fragrance beautiful flower which blooms during October to November and persist for about 20 days. Commonly it is called the 'Ocher Yellow Coelogyne'. Its flower is apple green or light yellow in color. Its pseudobulb looks like banana so the local people also know it with the name of 'Ban-kera'. Local people use this species for its medicinal properties. Paste and juice of its pseudobulbs are used for abdominal pain and burns (Pant \& Raskoti, 2013). Deforestation and uncontrolled collection from wild for ornamental and medicinal purposes are decreasing the population of this species in nature. So, conservation of this species is an urgent need. Plant tissue culture techniques provide an alternative tool for their rapid propagation in vitro. The present research highlighted on asymbiotic seed germination and plantlet development of $C$. fuscescens.

\section{MATERIALS AND METHODS}

The materials used for the present investigation were the young capsules of Coelogyne fuscescens Lindl. collected from the Thulswara V.D.C - 1, Kaski, Nepal.

\section{Culture media}

Murashige \& Skoog (MS) medium (1962) was taken as a basal medium either alone or in combination with different plant growth regulators for this investigation. Media was fortified with 3\% sucrose and different concentrations of BAP and NAA (Table 1). The $\mathrm{pH}$ of

Author for Correspondence: Bijaya Pant, Central Department of Botany, Tribhuvan University, Kirtipur, Nepal. E-mail: pant_bijaya@yahoo.com. 
medium was adjusted at 5.8 by using $0.1 \mathrm{~N} \mathrm{NaOH}$ and $0.1 \mathrm{~N} \mathrm{HCl}$ before gelling with $0.8 \%$ difco-bacto agar. Agar was dissolved by boiling the medium. About $20 \mathrm{ml}$ of molten medium was dispensed in each sterile culture tube and covered by aluminium foil before autoclaving at $1.05 \mathrm{~kg} / \mathrm{cm}^{2}$ at $121^{\circ} \mathrm{C}$ for $20 \mathrm{~min}$. After autoclaved, the cultures were maintained at $25( \pm 2)^{\circ} \mathrm{C}$ under $16 / 8 \mathrm{hrs}$ photoperiod.

\section{Sterilization and inoculation of seeds}

Before inoculation, the laminar airflow chamber was sterilized by cleaning it with cotton soaked with $70 \%$ alcohol. All the requirements for inoculation i.e. $70 \%$ ethyl alcohol, sodium hypochlorite solution( $1 \%)$, sterile distilled water, aluminium foils, petridishes, surgical blade, spatula, beaker, forceps, culture tubes with media were exposed under ultraviolet (UV) radiation for 45 minutes to remove the possible contaminants presenting on them and around the transfer area. After UV exposure, the blower was switched on for 15 minutes. Then, the laminar air-flow chamber was ready for inoculation.

Since the immature capsules of the orchids were collected from the plants grown in natural habitat, they need proper sterilization before their culture. For their sterilization capsules were dipped in detergent water for few minutes then washed in running water for 1 hour. The capsules were then rinsed with distilled water. Inside the laminar airflow, capsules were dipped in $70 \%$ ethyl alcohol for 2 minutes and surface sterilized in $1 \%$ sodium hypochlorite solution for 15 minutes. Finally, the capsules were washed with sterile water for five times. The capsules were cut longitudinally into two equal halves and the seeds were inoculated on MS medium alone and in various combination and concentrations of hormones (BAP + NAA). Sterile spatula was used to scope out and spread the seed on agar medium and observed regularly. All the cultures were maintained at $25( \pm 2){ }^{\circ} \mathrm{C}$ temperatures under $16 / 8$ hours photoperiods.

\section{RESULT AND DISCUSSION}

The germination of the orchid seed is rather difficult in comparisons to the germination of other angiospermic seeds, because they lack endosperm, radical and leaf rudiments. In nature they need the mycorrhizal symbiosis for the germination which takes very long time. So tissue culture technique proves itself a reliable and promising method for the conservation of orchids.

Immature seeds of $C$. fuscescens was used for the in vitro seed germination and seedling development. Seeds were cultured on MS medium supplemented with various concentration of NAA $(0.5 \mathrm{mg} / \mathrm{l})$ and BAP $(0.5-2 \mathrm{mg} / \mathrm{l})$ and without hormone supplement. Almost all conditions favoured seeds germination. MS medium supplemented with BAP (1.0 mg/l) + NAA $(0.5 \mathrm{mg} / \mathrm{l})$ was found to be good culture condition for the earlier germination of seeds whereas MS medium supplemented with NAA( 0.5 $\mathrm{mg} / \mathrm{l}$ ) was the most favourable condition for germination as well as seedling development of C. fuscescens. The most appropriate condition for the germination of the seeds was concluded on the basis of time taken for the germination, efficiency of germination and growth and development of the seedlings.

After germination, seeds underwent further differentiation to form seed clumps, protocorms which finally gave rise to complete plantlets. The protocorms of $C$. fuscescens were found to be indistinct, grey in colour from which green plantlets were raised.

Culture conditions: MS medium, $25 \pm 2^{\circ} \mathrm{C}, 16 / 8 \mathrm{hrs}$ photoperiod, 32 weeks, 4 replicates were used in each combination.

In vitro seed germination of orchids is greatly influenced by several factors such as age of the seeds, nutrient media, organic carbon sources, different adjuncts and quality and quantity of plant growth regulators (Pongener and Deb, 2009). MS medium supplemented with various concentrations of plant growth regulators (BAP and NAA) was effective for in vitro seed germination of C. fuscescens. The first visible sign of germination i.e. swelling of embryo was started after 6 weeks of culture and about $90 \%$ of seeds were germinated on MS + BAP $(1 \mathrm{mg} / \mathrm{l})+\mathrm{NAA}(0.5 \mathrm{mg} / \mathrm{l})$. In this condition, swelling embryo later developed into green spherules protocorms after 10 weeks of culture and finally the shoots were initiated after 13 weeks of culture. In spite of vigorous germination of the seeds the root primordia were not seen in this condition even after 32 weeks of culture. This condition was followed by MS + NAA $(0.5 \mathrm{mg} / \mathrm{l})$ and MS + BAP $(0.5 \mathrm{mg} / \mathrm{l})+\mathrm{NAA}(0.5 \mathrm{mg} / \mathrm{l})$ where the germination started after 9 and 10 weeks of culture respectively. Germination and differentiation were also satisfactory in hormone free MS media.

Combined treatment of BAP and NAA proved to be beneficial in promoting germination and shoot development in all tested conditions. Lower concentration of BAP either alone or in combination with NAA was found to be effective for germination while its higher concentration took longer period. It might be due to the genetic constitution of the species and interaction between the growth stimulating substances. Though all the tested conditions favoured seed germination, the complete seedling was developed only on MS + NAA $(0.5 \mathrm{mg} / \mathrm{l})$. These results showed that media fortified with only NAA was appropriate for giving shoot and root development in this species.

Initiation of germination, protocorm formation and subsequent growth and development of seedlings varies 
Table1: Effect of growth regulators supplemented in MS medium for seed germination and seedling growth of $C$.

fuscescens Lindl.

\begin{tabular}{|c|c|c|c|c|c|c|}
\hline \multirow[t]{2}{*}{ Media } & \multirow{2}{*}{$\begin{array}{l}\text { Growth } \\
\text { Hormones }\end{array}$} & \multirow{2}{*}{$\begin{array}{l}\text { Concentration of } \\
\text { hormones }(\mathrm{mg} / \mathrm{l})\end{array}$} & \multicolumn{4}{|c|}{ Observation taken in weeks } \\
\hline & & & $\begin{array}{l}\text { Initiation of } \\
\text { germination }\end{array}$ & $\begin{array}{l}\text { Protocorm } \\
\text { formation }\end{array}$ & $\begin{array}{l}\text { Initiation of } \\
\text { shoots }\end{array}$ & $\begin{array}{l}\text { Initiation } \\
\text { of roots }\end{array}$ \\
\hline MS & BM & - & 10 & 13 & 17 & - \\
\hline “ & BAP & 0.5 & 12 & 15 & 19 & - \\
\hline “ & BAP & 1.0 & 15 & 18 & 21 & - \\
\hline “ & BAP & 1.5 & 13 & 15 & 19 & - \\
\hline “ & BAP & 2.0 & 18 & 22 & 28 & - \\
\hline “ & NAA & 0.5 & 9 & 12 & 16 & 23 \\
\hline “ & $\mathrm{BAP}+\mathrm{NAA}$ & $0.5+0.5$ & 10 & 12 & 15 & - \\
\hline “ & $\mathrm{BAP}+\mathrm{NAA}$ & $1+0.5$ & 6 & 10 & 13 & - \\
\hline “ & $\mathrm{BAP}+\mathrm{NAA}$ & $1.5+0.5$ & 12 & 14 & 17 & - \\
\hline “ & $\mathrm{BAP}+\mathrm{NAA}$ & $2.0+0.5$ & 17 & 20 & 22 & \\
\hline
\end{tabular}

with the species and the medium employed (Reddy et al, 1992, Baskar \& Narmatha, 2010). In present investigation, earlier germination, protocorm formation and shoot development was observed on MS medium supplemented with BAP $(1 \mathrm{mg} / \mathrm{l})+$ NAA $(0.5 \mathrm{mg} / \mathrm{l})$. Similar findings were reported by various researchers in different orchids. Swar and Pant (2004) reported that MS medium supplemented with NAA $(1 \mathrm{mg} / \mathrm{l})$ and BAP $(1 \mathrm{mg} / \mathrm{l})$ was the most effective condition for the germination of Cymbidium iridioides. Jamir et al. (2002) found that asymbiotic germination was best in Nitsch medium supplemented with NAA and Kinetin at $1 \mathrm{mg} / \mathrm{l}$ each in C. iridioides. Kabita and Sharma (2001) observed that hundred percent germination was obtained on MS medium supplemented with NAA $(0.1 \mathrm{mg} / \mathrm{l})$ and $\mathrm{Kn}(1 \mathrm{mg} / \mathrm{l})$ in Acampe longifolia Lindl.

However the earlier germination on MS + BAP $(1 \mathrm{mg} / \mathrm{l})$ + NAA $(0.5 \mathrm{mg} / \mathrm{l})$ of this species was not effective for initiation of root. Complete plantlet was observed on MS medium supplemented with NAA $(0.5 \mathrm{mg} / \mathrm{l})$. Hence this condition was regarded as the best condition for germination and plantlet development of Coelogyne fuscescens which is in accord with the findings made by Shrestha (2005) who successfully achieved asymbiotic germination of $C$. ovalis Lindl. on MS medium supplemented with NAA $(1 \mathrm{mg} / \mathrm{l})$. Luan et al. (2006) also found high germination rate on $1 / 2 \mathrm{MS}$ medium containing NAA $(0.5 \mathrm{mg} / \mathrm{l})$ and $20 \% \mathrm{CW}$ in Dendrobium supperbum, D. wardianum, $D$. nobile and D. primulinum.

\section{CONCLUSION}

Coelogyne fuscescens is one of the beautiful fragrant orchids highly exploited for ornamental and medicinal purpose. In the present investigation, MS media supplemented with NAA $(0.5 \mathrm{mg} / \mathrm{l})$ was the appropriate condition for seed germination, protocorm formation and seedling development of this species. Hence, the present

investigation might be useful for ex situ conservation of this species and also fulfil the commercial demand of this species by using in vitro seed culture techniques.

\section{ACKNOWLEDGEMENT}

Authors are grateful to Central Department of Botany, Tribhuvan University, Kirtipur for providing laboratory facilities to conduct this research work. 


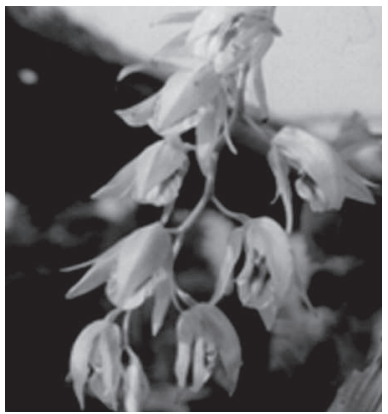

A

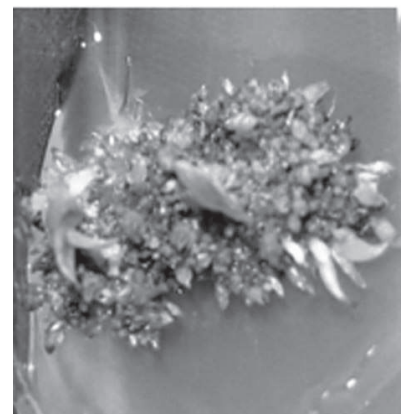

B

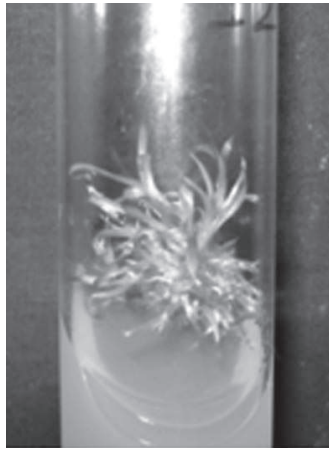

C

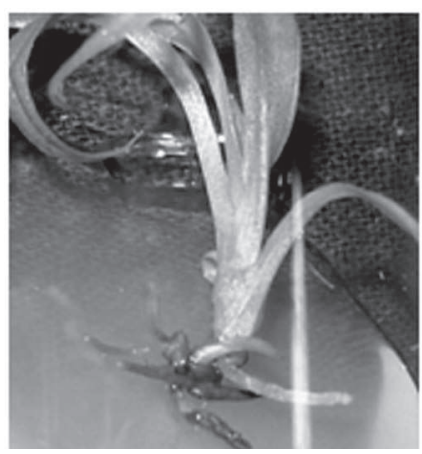

D

Fig.1. Asymbiotic seed germination and plantlet development of Coelogyne fuscescens. A. Flower of $C$. fuscescens in natural habitat, B. Small protocorms, pseudobulbs and leaves developed on MS + BAP (0.5 mg/l) + NAA (0.5 mg/l), C. Multiple shoot developed on MS + BAP (1 mg/l) + NAA (0.5 mg/l), D. Complete plantlet developed on MS + NAA (0.5 mg/l).

\section{REFERENCES}

Baral, S.R. and Kurmi, P.P. 2006. A Compendium of Medicinal Plants of Nepal. Mass Printing Press, Kathmandu, Nepal

Basker, S. and Narmatha Bai, V. 2010. In vitro propagation of an epiphytic and rare orchid Eria bambusifolia Lindl.Research in Biotechnology. 1: 15-20.

Hossain, M.M. 2008. Asymbiotic seed germination and in vitro seedling development of Epidendrum ibaguense Kunth.(Orchidaceae). African Journal of Biotechnology 7: 3614-3619.

Jamir, C., Devi, J. and Deka, P.C. 2002. In vitro propagation of Cymbidium iridiodes and C. lowianum, J. Orchid Soc. India. 16 (12): $83-89$.

Kabita, M. and Sharma, C.M. 2001. Selection of Suitable medium for in vitro germination and protocorm formation of Acampe longifolia Lindl. Advances in plant sciences. 14 (1): 243-248.

Luan, V.Q., Thien, N.Q., Khiem, D.V. and Nhut, D.T. 2006. In vitro germination capacity and plant recovery of some native and rare orchids. Proceedings of International Workshop on Biotechnology in Agriculture. Nong Lam University Ho Chi Minh City. October 20-21.

Mitra, G. 1986. In vitro culture of orchid seeds for obtaining seedlings. Biology, conservation, and culture of orchids: papers presented at a national seminar organized oby the Orchid Society of India, held at Panjab University, 3-4 April 1985. Published for the Orchid Society of India [by] Affiliated East-West Press. pp: 401.

Murashige, T. and F, Skoog. 1962. A revised medium for rapid growth and bio assay with tobacco tissue cultures. Physiol. Plant. 15: 473497.
Pant, B., Shrestha, S. and Pradhan, S. 2011. In vitro seed germination and seedling development of Phaius tancarvilleae (L'Her.) Blume. Scientific World. 9: 50-52.

Pant, B. and Raskoti, B.B. 2013. Medicinal Orchids of Nepal. Himalayan Map House, Pvt. Ltd., Nepal.

Pongener, A. and Deb, C.R. 2009. Asymbiotic culture of immature embryos, mass multiplication of Cymbidium iridioides D.Don. and the role of different factors. International Journal of Pharma and Bio Sciences. 1(1).

Raskoti, B.B. 2009. The Orchids of Nepal. Published by Bhakta Bahadur Raskoti and Rita Ale, Kathmandu, Nepal.

Reddy, P.V., Nanjan, K. and Shanmugavelu, K.G. 1992. In vitro studies in tropical orchids: Seed germination and seedling growth. $J$. Orchid soc. India. 6 (1-2): 75-78.

Shrestha, A. 2005. Ex situ conservation of Coelogyne ovalis Lindl. (Orchidaceae) through micropropagation. M.Sc. Dissertation, Central Department of Botany, T.U., Kathmandu, Nepal.

Stewart, S.L. and Kane, M.E. 2006. Asymbiotic seed germination and in vitro seedling development of Habenaria macroceratitis (Orchidaceae), a rare Florida terrestrial orchid. Plant Cell, Tissue and Organ Culture. 86: 147-158.

Swar, S. and Pant, B. 2004. Micropropagation of Cymbidium iridiodes D.Don. In Proceeding 4th National conference on Science and Technology RONAST, March 23-26, Kathmandu, Nepal.

White, C. and Sharma, B. 2000. Wild Orchids of Nepal: A guide to the Himalayan orchids of Tribhuvan Rajpath and Chitwan Jungle. White Lotus Press, Bangkok, Thailand. 